Suherman, C. $\cdot$ A. Nuraini $\cdot$ R. Damayanthi

\title{
Pengaruh konsentrasi giberelin dan pupuk organik cair asal rami terhadap pertumbuhan dan hasil tanaman rami (Boehmeria nivea L. (Gaud)) klon Ramindo 1
}

\section{The effect of gibberellic acid (GA) and liquid organic fertilizer (LOF) to ramie on growth and yield of ramie plant (Boehmeria nivea $\mathrm{L}$. (Gaud)) clone Ramindo 1}

\author{
Diterima : 15 November 2016/Disetujui : 15 Desember 2016 / Dipublikasikan : 30 Desember 2016 \\ CDepartment of Crop Science, Padjadjaran University
}

\begin{abstract}
The aim of this research was to observe the effected of gibberellic acid and liquid organic fertilizer (LOF) on growth of ramie in order to obtain one of gibberellic acid and liquid organic fertilizer combination concentration which affected on growth and fiber yield of Ramindo 1 ramie clone. The experiment was carried out from January to March 2016 at Ciparanje field trials, University of Padjadjaran, Jatinangor with altitude about $829 \mathrm{~m}$ above the sea level, Inceptisol type of soil, type $\mathrm{C}$ of rainfall according to Schmidt and Fergusson Classification (1951). The experiment which was used Randomized Block Design (RBD) which consisted of eight treatments and four repetition, in doing of the combination of GA0 ppm+ without LOF, GA 50 ppm + without LOF, GA100 ppm + without LOF, GA150 ppm + without LOF, GA0 ppm + LOF $40 \mathrm{ml} / \mathrm{L}$, GA50 ppm + LOF $40 \mathrm{ml} / \mathrm{L}$, GA100 ppm + LOF 40 $\mathrm{ml} / \mathrm{L}, \mathrm{GA} 150 \mathrm{ppm}+\mathrm{LOF} 40 \mathrm{ml} / \mathrm{L}$. The result of the experiment showed that the treatment of gibberellic acid concentration and liquid organic fertilizer combination could affect the growth and the production Ramindo 1 ramie clone. The treatment of GA $150 \mathrm{ppm}+40 \mathrm{ml} / \mathrm{L} \mathrm{LOF}$ may improved plant height, stem diameter, dry plant weight, fresh plant weight, and ramie fresh stem weight of Ramindo 1 ramie clone.
\end{abstract}

Keywords : Gibberellic acid · Liquid organic fertilizer - Ramie

Sari Rami adalah salah satu jenis tanaman

\begin{tabular}{l}
\hline Dikomunikasikan oleh Santi Rosniawaty \\
\hline${\text { Suherman C. }{ }^{1} \cdot \text { A. Nuraini }{ }^{1} \cdot \text { R. Damayanthi' }}^{2}$ \\
${ }^{1}$ Dosen Fakultas Pertanian, Universitas Padjadjaran Jl. \\
Raya Jatinangor Km. 21 Jatinangor, Sumedang 45363 \\
${ }^{2}$ Alumni Program Studi Agroteknologi, Fakultas Pertanian, \\
Universitas Padjadjaran \\
Jl. Raya Bandung-Sumedang Km 21, Jatinangor Sumedang \\
Korespondensi e-mail: cucu.suherman@unpad.ac.id
\end{tabular}

penghasil serat yang memiliki potensi hasil lebih tinggi dibanding tanaman kapas. Salah satu faktor penentu tinggi rendahnya hasil adalah panjang dan jumlah serat, yang antara lain ditentukan oleh tinggi dan diameter batang tanaman. Penelitian ini bertujuan untuk mengetahui pengaruh konsentrasi giberelin dan pupuk organik cair rami serta memperoleh salah satu kombinasi konsentrasi giberelin dan POC rami yang memberikan pengaruh terbaik pada pertum-buhan dan hasil serat tanaman rami klon Ramindo 1. Percobaan dilaksanakan dari bulan Januari 2016 sampai bulan Maret 2016 di kebun percobaan Ciparanje Faperta Universitas Padjadjaran, Jatinangor, dengan ketinggian tempat mencapai $829 \mathrm{~m}$ di atas permukaan laut, dengan tanah ordo Inceptisol, dan tipe iklim berdasarkan klasifikasi Schmidt dan Ferguson (1951) termasuk tipe C. Rancangan yang digunakan dalam penelitian ini adalah Rancangan Acak Kelompok (RAK) yang terdiri dari 8 perlakuan dan diulang sebanyak 4 kali, dengan perlakuan kombinasi GA0 ppm+ tanpa POC, GA50 ppm + tanpa POC, GA100 ppm + tanpa POC, GA150 ppm + tanpa POC, Larutan GA0 $\mathrm{ppm}+40 \mathrm{ml} / \mathrm{L}$ POC, GA50 ppm $+40 \mathrm{ml} / \mathrm{L}$ POC, GA100 ppm + $40 \mathrm{ml} / \mathrm{L}$ POC, GA150 ppm + 40 $\mathrm{ml} / \mathrm{L}$ POC. Hasil percobaan menunjukkan bahwa pemberian kombinasi dosis giberelin dan pupuk organik cair rami dapat mempengaruhi pertumbuhan dan hasil serat tanaman rami klon Ramindo 1. Perlakuan GA 150 ppm dan $40 \mathrm{ml} / \mathrm{L}$ pupuk organik cair (POC) dapat meningkatkan tinggi tanaman, diameter batang, bobot kering tanaman, bobot basah tanaman, dan bobot segar batang tanaman rami klon Ramindo 1.

Kata kunci : Giberelin · Pupuk organik cair . Rami 


\section{Pendahuluan}

Indonesia merupakan salah satu negara yang banyak memanfaatkan serat kapas sebagai bahan baku industri tekstilnya. Hal ini terbukti dari kebutuhan kapas Indonesia yang mencapai 500.000 ton per tahun. sebagian besar (99\%) dipenuhi dengan impor dari berbagai negara. Hal ini disebabkan karena produksi kapas dalam negeri hanya mencapai 5.000 ton per tahun (Juhana dkk., 2011).

Untuk mengatasi ketergantungan tersebut, maka perlu dicari tanaman penghasil serat selain kapas, salah satunya adalah tanaman rami. Tanaman rami, selain memiliki karakteristik yang hampir sama dengan tanaman kapas (Musaddad, 2007), juga memiliki serat yang lebih panjang, kekuatan serat yang lebih besar, dan daya serap air yang lebih besar dibandingkan serat yang berasal dari kapas. Serat rami lebih kasar dan daya elastisitas lebih rendah dibanding serat kapas. Hal ini berkaitan dengan sifat fisik dan kandungan bahan kimia yang terdapat pada serat rami (Purwati, 2010).

Serat rami dapat diolah menjadi bahan baku kain berkualitas tinggi dan bahan pembuatan selulosa a. Selulosa a merupakan salah satu unsur pokok dalam pembuatan bahan peledak dan baju anti peluru (Tim puslitbang, 2012).

Tanaman rami merupakan tanaman yang memiliki pertumbuhan vegetatif yang cepat. Hal ini menyebabkan rami membutuhkan air yang cukup dan tersedia sepanjang tahun, serta tanah yang subur untuk mendukung pertumbuhannya. Tanaman rami dapat tumbuh pada ketinggian 0 $1.500 \mathrm{~m}$ diatas permukaan laut. Ketinggian tempat yang optimum untuk pertumbuhan rami adalah $800-1.300 \mathrm{~m}$ di atas permukaan laut, dengan ratarata curah hujan 1.200-2.000 mm/tahun. Tanaman rami yang ditanam pada daerah dengan curah hujan yang merata, dapat dipanen 5 - 6 kali dalam setahun, diluar daerah itu maka pada penanaman rami dibutuhkan tambahan irigasi selama bulanbulan kering. Suhu yang sesuai bagi pertumbuhan tanaman rami adalah $22^{\circ}-28{ }^{\circ} \mathrm{C}$ dengan kelembapan 40 - 90 \% (Musaddad, 2007).

Produktivitas serat tanaman rami tergantung pada batang tanaman rami itu sendiri, sehingga dalam sistem budidayanya dibutuhkan suatu bahan yang dapat membantu tanaman untuk menghasilkan tinggi dan diameter batang yang sesuai, sehingga dapat menghasilkan serat rami yang berkualitas (Sujdatmiko, 2013).
Banyak faktor yang dapat mempengaruhi pertumbuhan dan perkembangan tanaman, salah satunya adalah Zat Pengatur Tumbuh (ZPT). Diantara ZPT yang banyak digunakan adalah giberelin (GA). GA merupakan zat yang dapat mengatur proses perkembangan tanaman, seperti memacu pertumbuhan tanaman menjadi lebih cepat, mempengaruhi sifat genetik dan proses fisiologis tumbuhan. Salah satu peran giberelin (GA) dalam merangsang pembelahan sel akan berkaitan dengan perpanjangan batang (Syafi'i, 2005)

Menurut Mudyantini (2008), pemberian GA pada tanaman rami dapat meningkatkan jumlah floem yang terbentuk, dimana peningkatan jumlah floem ini akan memacu peningkatan selulosa dan lignin. Selulosa dan lignin merupakan salah satu faktor penentu kualitas serat rami.

Hasil penelitian yang dilakukan oleh Maruapey (2013) pada setek tanaman tebu, menunjukkan bahwa pemberian giberelin dengan konsentrasi 75 ppm dapat meningkatkan tinggi tanaman, jumlah daun, jumlah ruas tanaman, diameter batang, jumlah akar tanaman, dan bobot brangkasan tebu.

Menurut Leovini (2012), pupuk organik cair adalah pupuk organik dengan wujud cair dan dalam pemanfaatannya, pupuk ini mudah larut dalam tanah, sehingga unsur hara yang terdapat di dalamnya mudah diserap oleh tanaman. Pemupukan dengan menggunakan POC memiliki keuntungan yaitu mudah dalam pengaplikasiannya dan lebih mudah diserap tanaman.

Berdasarkan penelitian yang dilakukan sebelumnya, sisa hasil panen rami dapat dimanfaatkan sebagai kompos yang dapat diaplikasikan kembali pada tanaman rami, salah satunya adalah pupuk organik cair. Pupuk organik cair asal rami memiliki kandungan bahan organik yang dapat membantu dalam pertumbuhan tanaman rami, serta dapat membantu dalam meningkatkan hasil dan kualitas serat dari tanaman rami (Hasil komunikasi dengan pihak peneliti dari Fakultas Matematika dan Pengetahuan Alam (MIPA), Universitas Padjadjaran ).

Percobaan ini bertujuan untuk mengetahui pengaruh konsentrasi GA dan POC asal rami terhadap pertumbuhan dan hasil serat pada tanaman rami (Boehmeria nivea) klon Ramindo 1 dan menemukan kombinasi konsentrasi manakah yang memberikan pengaruh yang paling baik. 


\section{Bahan dan Metode}

Percobaan telah dilaksanakan di Kebun Percobaan Ciparanje Fakultas Pertanian Universitas Padjadjaran, Jatinangor, Kabupaten Sumedang, Provinsi Jawa Barat. Ketinggian tempat sekitar $829 \mathrm{~m}$ di atas permukaan laut, dengan jenis tanah ordo Inceptisols, tipe iklim berdasarkan klasifikasi curah hujan Schmidt dan Fergusson (1951) termasuk tipe C. Percobaan dilaksanakan pada bulan Desember 2015 sampai Maret 2016.

Bahan yang digunakan dalam percobaan ini meliputi : polibeg ukuran $40 \mathrm{~cm}$ x $35 \mathrm{~cm}$, rhizoma rami yang berasal dari klon Ramindo 1 , top soil tanah Inceptisols, zat pengatur tumbuh Giberelin (GA), Pupuk organik cair (POC) asal rami, dan pupuk anorganik : Urea, SP-36, dan $\mathrm{KCl}$. Alat yang digunakan dalam percobaan ini adalah cangkul, pisau, alat tulis, label, alat penyiram, jangka sorong, penggaris atau meteran, oven, dan timbangan analitik

Media tanam yang digunakan yaitu tanah bagian atas ordo Inceptisols yang diperoleh dari lahan penelitian Ciparanje ditimbang sebanyak $12 \mathrm{~kg}$ per polybag dan dicampur dengan pupuk kandang ayam sebanyak $400 \mathrm{~g}$ per polibag.

Bibit yang digunakan dalam percobaan ini adalah bibit rami klon Ramindo 1 yang dipotong sepanjang 10-15 cm. Penanaman rhizoma dilakukan dengan membuat lubang tanam pada media di polibeg dengan kedalaman $5 \mathrm{~cm}$, rhizoma diletakkan miring kurang lebih $45^{\circ}$. Sebagian dibenamkan ke dalam tanah, kemudian tanah di sekitarnya dipadatkan.

Konsentrasi GA sesuai perlakuan, yaitu 0 ppm, 50 ppm, 100 ppm,150 ppm dan POC rami pada taraf $0 \mathrm{ml} / \mathrm{L}$ dan $40 \mathrm{ml} / \mathrm{L}$. GA dan POC masing masing diaplikasikan dengan cara disemprotkan kepada daun secara merata dengan dosis sesuai hasil kalibrasi. Aplikasi dilakukan pada 4 MST,6 MST, dan 8 MST.

Pemeliharaan tanaman rami meliputi penyulaman, penyiangan gulma, penyiraman, dan pengendalian hama dan penyakit. Penyulaman dilakukan pada 7-10 hari setelah tanam (HST) bila ada rhizoma yang pertumbuhannya tidak normal atau mati. Penyiangan gulma dilakukan setiap kali muncul gulma, dilakukan secara manual. Penyiraman dilakukan satu kali sehari, pagi hari.

Pemanenan tanaman rami dilakukan 90 hari (tiga bulan) setelah tanam. Variabel yang diamati adalah jumlah anakan, tinggi tanaman, diameter batang, dan jumlah daun, semuanya dilakukan pada 6 MST, 8 MST, 10 MST, dan 12 MST, pengamatan bobot basah tanaman, bobot segar batang per rumpun, dan bobot kering tanaman dilakukan pada umur tanaman 12 MST.

Percobaan menggunakan Rancangan Acak Kelompok (RAK), yang terdiri dari delapan perlakuan dan diulang empat kali. Perlakuannya adalah : $\mathrm{A}=\mathrm{GA} 0$ ppm+ tanpa POC asal rami, B = GA50 ppm + tanpa POC asal rami, $\mathrm{C}=$ GA100 ppm + tanpa POC asal rami, D = GA150 ppm + tanpa POC asal rami, E = GA0 ppm + 40 $\mathrm{ml} / \mathrm{L}$ POC asal rami, $\mathrm{F}=\mathrm{GA} 50 \mathrm{ppm}+40 \mathrm{ml} / \mathrm{L}$ POC asal rami, $\mathrm{G}=\mathrm{GA} 100 \mathrm{ppm}+40 \mathrm{ml} / \mathrm{L}$ POC asal rami, $\mathrm{H}=\mathrm{GA} 150 \mathrm{ppm}+40 \mathrm{ml} / \mathrm{L}$ POC asal rami, Setiap satuan percobaan terdiri dari tiga tanaman dan pengamatan dilakukan terhadap semua tanaman. Totsl Tanaman yang diperlukan berjumlah 96. Pengaruh perlakuan dianalisis melalui analisis ragam dengan uji $\mathrm{F}$ pada taraf 5 $\%$. Apabila terdapat perbedaan antar perlakuan, maka dilakukan uji lanjut dengan uji Lanjut Duncan pada taraf 5 \% (Gaspersz, 2006).

\section{Hasil dan Pembahasan}

Jumlah Anakan. Berdasarkan hasil analisis, pemberian GA dan POC rami menghasilkan pengaruh yang berbeda nyata hanya pada 8 MST, tetapi tidak memberikan pengaruh yang nyata terhadap pertumbuhan jumlah anakan pada 6, 10 dan 12 MST (Tabel 1).

Tabel 1 menunjukkan bahwa pada 8 MST pengaruh perlakuan A (kombinasi larutan GA 0 ppm + tanpa POC) menghasilkan jumlah anakan yang lebih banyak bila dibanding dengan pengaruh perlakuan $\mathrm{H}$ dan $\mathrm{D}$, namun pengaruh perlakuan A tidak berbeda nyata dengan pengaruh perlakuan lainnya. Tabel 1 juga menunjukkan bahwa semakin besar pemberian larutan GA yang dikombinasikan dengan taraf POC $40 \mathrm{ml} / \mathrm{L}$ cenderung semakin menurunkan jumlah anakan tanaman rami.

Jumlah anakan yang tumbuh dalam satu polibeg ditentukan oleh banyaknya anakan yang terdapat pada rhizoma pada saat awal penanaman. Banyaknya anakan di setiap potongan rhizoma rami ditentukan oleh jarak antar ruas pada rhizoma, yang merupakan faktor internal dari tanaman rami (Mudyantini, 2008).

Pada pengamatan 5, 10 dan 12 MST, perlakuan tidak memberikan pegaruh yag berbeda nyata diduga hal tersebut terjadi karena GA merupakan zat pengatur tumbuh yang 
Tabel 1. Pengaruh Konsentrasi Giberelin dan pupuk Organik Cair Rami terhadap Jumlah Anakan Tanaman Rami Klon Ramindo 1 pada 6 MST, 8 MST, 10 MST, dan 12 MST.

\begin{tabular}{ccccc}
\hline \hline \multirow{2}{*}{ Perlakuan } & \multicolumn{5}{c}{ Jumlah Anakan/Tunas } \\
\cline { 2 - 5 } & $6 \mathrm{MST}$ & $8 \mathrm{MST}$ & $10 \mathrm{MST}$ & $12 \mathrm{MST}$ \\
\hline $\mathrm{A}$ & $15,25 \mathrm{a}$ & $17,00 \mathrm{a}$ & $27,00 \mathrm{a}$ & $26,75 \mathrm{a}$ \\
$\mathrm{B}$ & $11,75 \mathrm{a}$ & $12,50 \mathrm{ab}$ & $18,50 \mathrm{a}$ & $22,00 \mathrm{a}$ \\
$\mathrm{C}$ & $12,00 \mathrm{a}$ & $13,00 \mathrm{ab}$ & $19,50 \mathrm{a}$ & $24,75 \mathrm{a}$ \\
$\mathrm{D}$ & $10,75 \mathrm{a}$ & $11,00 \mathrm{~b}$ & $17,25 \mathrm{a}$ & $18,00 \mathrm{a}$ \\
E & $13,50 \mathrm{a}$ & $16,00 \mathrm{ab}$ & $25,25 \mathrm{a}$ & $25,75 \mathrm{a}$ \\
F & $13,00 \mathrm{a}$ & $12,75 \mathrm{ab}$ & $22,25 \mathrm{a}$ & $23,25 \mathrm{a}$ \\
$\mathrm{G}$ & $12,00 \mathrm{a}$ & $12,00 \mathrm{ab}$ & $21.75 \mathrm{a}$ & $22,25 \mathrm{a}$ \\
$\mathrm{H}$ & $13,25 \mathrm{a}$ & $12,50 \mathrm{ab}$ & $19,75 \mathrm{a}$ & $16,50 \mathrm{a}$ \\
\hline \hline
\end{tabular}

Keterangan : Nilai rata-rata perlakuan yang ditandai dengan huruf yang sama pada kolom yang sama, menunjukkan tidak berbeda nyata menurut uji jarak berganda Duncan pada taraf $5 \%$.

mengatur perpanjangan sel, perkecambahan, dan perkembangan bunga dan biji, sehingga pemberian GA pada tanaman rami tidak memberikan efek yang berbeda bila dibanding dengan tanaman rami yang tidak diberi GA. Pada wktu pengamatan tersebut, pemberian POC (Pupuk Organik Cair) asal rami, juga tidak memberikan pengaruh yang berbeda nyata terhadap pertumbuhan anakan tanaman rami. Aplikasi pupuk organik cair dengan cara penyemprotan melalui daun pada tanaman, bermanfaat untuk melengkapi pemberian pupuk melalui tanah. Hal ini juga berperan dalam meminimalisir terjadinya kekurangan unsur hara pada tanaman (Leovini, 2012).

Jumlah Daun. Hasil analisis statistik perlakuan kombinasi konsentrasi giberelin dan pupuk organik cair rami pada tanaman rami umur 8 MST dan 10 MST menghasilkan jumlah daun yang berbeda antar perlakuan. Sedangkan pada umur 6 dan 12 MST tidak menghasilkan perbedaan yang nyata di antara perlakuan (Tabel 2).

Pada usia tanaman rami 8 MST dan 10 MST, pengaruh perlakuan $\mathrm{H}$ berbeda nyata dengan perlakuan A, namun tidak berbeda dengan pengaruh perlakuan lainnya. Pengaruh perlakuan $\mathrm{H}$ (kombinasi Larutan GA $150 \mathrm{ppm}+40 \mathrm{ml} / \mathrm{L}$ POC) memiliki jumlah daun yang lebih banyak dibanding dengan pengaruh perlakuan A. Pengaruh perlakuan A (kombinasi Larutan GA 0 ppm + tanpa POC) menghasilkan jumlah daun yang lebih sedikit dibanding pengaruh perlakuan $\mathrm{H}$.

Hal ini disebabkan jumlah dan ukuran daun biasanya ditentukan juga oleh faktor genetis tanaman dan lingkungan sekitar (Gardner dkk., 1991).
Tabel 2. Pengaruh Konsentrasi Giberelin dan pupuk Organik Cair Rami terhadap Jumlah Daun Tanaman Rami Klon Ramindo 1 pada 6 MST, 8 MST, 10 MST, dan 12 MST.

\begin{tabular}{ccccc}
\hline \hline \multirow{2}{*}{ Perlakuan } & \multicolumn{4}{c}{ Jumlah Daun } \\
\cline { 2 - 5 } & $6 \mathrm{MST}$ & $8 \mathrm{MST}$ & $10 \mathrm{MST}$ & $12 \mathrm{MST}$ \\
\hline $\mathrm{A}$ & $69,75 \mathrm{a}$ & $93,25 \mathrm{~b}$ & $146,25 \mathrm{~b}$ & $171,00 \mathrm{a}$ \\
$\mathrm{B}$ & $72,75 \mathrm{a}$ & $102,25 \mathrm{ab}$ & $165,75 \mathrm{ab}$ & $182,75 \mathrm{a}$ \\
$\mathrm{C}$ & $74,75 \mathrm{a}$ & $106,75 \mathrm{ab}$ & $165,75 \mathrm{ab}$ & $194,50 \mathrm{a}$ \\
$\mathrm{D}$ & $70,75 \mathrm{a}$ & $109,75 \mathrm{ab}$ & $170,75 \mathrm{ab}$ & $202,25 \mathrm{a}$ \\
$\mathrm{E}$ & $72,00 \mathrm{a}$ & $99,00 \mathrm{~b}$ & $154,75 \mathrm{ab}$ & $177,00 \mathrm{a}$ \\
$\mathrm{F}$ & $75,25 \mathrm{a}$ & $108,00 \mathrm{ab}$ & $162,75 \mathrm{ab}$ & $187,25 \mathrm{a}$ \\
$\mathrm{G}$ & $74,75 \mathrm{a}$ & $108,25 \mathrm{ab}$ & $168,25 \mathrm{ab}$ & $196,75 \mathrm{a}$ \\
$\mathrm{H}$ & $81,25 \mathrm{a}$ & $122,50 \mathrm{a}$ & $180,25 \mathrm{a}$ & $194,25 \mathrm{a}$ \\
\hline \hline
\end{tabular}

Keterangan : Nilai rata-rata perlakuan yang ditandai dengan huruf yang sama pada kolom yang sama, menunjukkan tidak berbeda nyata menurut uji jarak berganda Duncan pada taraf $5 \%$.

Ada kecenderungan dampak yang berbanding terbalik pengaruh perlakuan terhadap jumlah anakandan jumlah daun. Perlakuan yang menghasilkan jumlah anakan yang banyak, menghasilkan jumlah daun yang sedikit, demikian sebaliknya.

Faktor lingkungan yang juga dapat mempengaruhi jumlah daun adalah cahaya. Jika tanaman rami berada pada daerah dengan sinar matahari yang cukup, maka akan menghasilkan jumlah daun yang lebih banyak, karena fotosintat yang dihasilkan lebih banyak dari proses fotosintesis yang lancar, akibat jumlah cahaya matahari yang cukup. Jumlah daun pada tanaman rami ini juga dipengaruhi oleh tinggi tanaman dan jumlah anakan yang tumbuh dalam satu polibeg.

Bobot Basah Tanaman. Menurut Mudyantini (2008), bobot basah tanaman merupakan banyaknya kandungan air yang berada di dalam organ tanaman, selain kandungan bahan organik. Bobot basah menunjukkan bagaimana proses metabolisme yang terjadi dalam tanaman. Kadar bobot basah tanaman dipengaruhi oleh kadar air yang terdapat pada jaringan atau organ tubuh tanaman, unsur hara, dan bahan organik yang terkandung dalam suatu tanaman.

Hasil analisis data menunjukkan bahwa pemberian kombinasi pupuk organik cair asal rami dan giberelin memberikan pengaruh yang nyata pada bobot basah tanaman rami. Perlakuan $\mathrm{H}$ dengan menggunakan giberelin $150 \mathrm{ppm}$ dan pupuk organik cair $40 \mathrm{ml} / \mathrm{L}$ menghasilkan bobot basah tanaman yang paling besar, dimana pengaruh perlakuan ini berbeda nyata dengan perlakuan $\mathrm{A}$ dan $\mathrm{E}$ yang tidak menggunakan larutan giberelin (Tabel 3). 
Tabel 3. Pengaruh Konsentrasi Giberelin dan Pupuk Organik Cair Rami terhadap Bobot Basah Tanaman Rami Klon Ramindo 1 pada 12 MST.

\begin{tabular}{cc}
\hline \hline Perlakuan & Bobot Basah Tanaman $(\mathrm{g})$ \\
\hline A & $606,25 \mathrm{~cd}$ \\
B & $661,25 \mathrm{bc}$ \\
$\mathrm{C}$ & $687,50 \mathrm{ab}$ \\
$\mathrm{D}$ & $727,50 \mathrm{ab}$ \\
$\mathrm{E}$ & $583,75 \mathrm{~d}$ \\
$\mathrm{~F}$ & $680,00 \mathrm{ab}$ \\
$\mathrm{G}$ & $701,25 \mathrm{ab}$ \\
$\mathrm{H}$ & $732,50 \mathrm{a}$ \\
\hline \hline
\end{tabular}

Keterangan : Nilai rata-rata perlakuan yang ditandai dengan huruf yang sama pada kolom yang sama, menunjukkan tidak berbeda nyata menurut uji jarak berganda Duncan pada taraf $5 \%$.

Perlakuan yang menghasilkan bobot basah tanaman terbesar adalah perlakuan $\mathrm{H}$, yaitu pemberian kombinasi larutan GA 150 ppm + 40 $\mathrm{ml} / \mathrm{L}$ POC. Kondisi tersebut menunjukkan bahwa kombinasi perlakuan GA dan POC mempengaruhi bobot basah tanaman rami. Dalam hal ini pemberian giberelin dalam taraf 150 ppm mampu mempengaruhi pembelahan sel tanaman rami yang berkaitan dengan jumlah, pembesaran dan, peningkatan ukuran sel tanaman rami lebih dari sel induk. Pertambahan ini menyebabkan pertambahan ukuran organ tanaman dan akhirnya meningkatkan ukuran organ tanaman secara keseluruhan, yang berkaitan juga dengan pertambahan bobot tanaman secara keseluruhan (Mudyantini, 2008).

Pupuk organik cair yang digunakan dalam percobaan ini juga memberikan pengaruh pada bobot basah tanaman rami. Pupuk organik cair asal rami mengandung persentase kandungan unsur $\mathrm{N}, \mathrm{P}$, dan $\mathrm{K}$ yang tidak terlalu tinggi. Namun, pemberian pupuk organik cair $40 \mathrm{ml} / \mathrm{L}$ pada tanaman rami sudah mampu meningkatkan pertumbuhan tanaman, sehingga menghasilkan tanaman dengan bobot basah yang cukup besar.

Kandungan $\mathrm{K}$ dalam pupuk organik cair juga membantu dalam mengatur keluar masuknya $\mathrm{CO}_{2}$ ke dalam stomata tanaman, dimana hal ini berkaitan dengan proses fotosintesis pada tanaman. Proses fotosintesis berkaitan dengan pengubahan karbondioksida menjadi karbohidrat, dimana hasil fotosintesis akan dimanfaatkan untuk pertumbuhan dan perkembangan organ tanaman (Munawar, 2011).

Bobot Kering Tanaman. Berdasarkan hasil analisis statistik, kombinasi pemberian giberelin dan pupuk organik cair asal rami memberikan pengaruh yang nyata pada bobot kering tanaman rami. Berdasarkan uji lanjut Duncan seperti yang tertera pada Tabel 4, menunjukkan bahwa perlakuan $\mathrm{H}(\mathrm{GA} 150 \mathrm{ppm}+40 \mathrm{ml} / \mathrm{L}$ POC) menghasilkan bobot kering tanaman yang lebih besar bila dibandingkan dengan perlakuan lainnya kecuali perlakuan D. Perlakuan $H$ dengan taraf konsentrasi giberelin $150 \mathrm{ppm}$ dan pupuk organik cair asal tanaman rami $40 \mathrm{ml} / \mathrm{L}$, mampu menyediakan unsur hara bagi tanaman untuk meningkatkan pertumbuhan dan perkembangan tanaman.

Tabel 4. Pengaruh Konsentrasi Giberelin dan pupuk Organik Cair Rami terhadap Bobot Kering Tanaman Rami Klon Ramindo 1 pada 12 MST.

\begin{tabular}{cc}
\hline \hline Perlakuan & Bobot Kering Tanaman $(\mathrm{g})$ \\
\hline A & $227,33 \mathrm{bc}$ \\
B & $227,05 \mathrm{bc}$ \\
C & $202,55 \mathrm{c}$ \\
D & $255,33 \mathrm{ab}$ \\
E & $212,70 \mathrm{c}$ \\
F & $204,43 \mathrm{c}$ \\
G & $229,08 \mathrm{bc}$ \\
H & $265,03 \mathrm{a}$ \\
\hline \hline
\end{tabular}

Keterangan : Nilai rata-rata perlakuan yang ditandai dengan huruf yang sama pada kolom yang sama, menunjukkan tidak berbeda nyata menurut uji jarak berganda Duncan pada taraf $5 \%$.

Bobot kering tanaman terbesar terdapat pada tanaman rami yang diberi kombinasi konsentrasi GA $150 \mathrm{ppm}+40 \mathrm{ml} / \mathrm{L}$ POC, dan bobot terkecil terdapat pada tanaman yang diberi konsentrasi GA dibawah 150 ppm yang dikombinasikan dengan $40 \mathrm{ml} / \mathrm{L}$ POC atau tanpa kombinasi POC. Hal ini sesuai dengan penelitian yang dilakukan oleh Mudyantini (2008), bahwa dosis pemberian giberelin tertinggi pada tanaman rami adalah $200 \mathrm{ppm}$ dan dosis pemberian giberelin terendah adalah $150 \mathrm{ppm}$ yang dapat memberikan pengaruh pada bobot kering tanaman rami. Pada konsentrasi dibawah dari 150 ppm, bobot kering tanaman masih cenderung kecil, sedangkan pada konsentrasi giberelin lebih dari 200 ppm, diduga akan menghambat pertumbuhan tanaman rami.

Kombinasi giberelin 150 ppm dengan POC asal rami konsentrasi $40 \mathrm{ml} / \mathrm{L}$ mempengaruhi bobot kering tanaman rami. Diduga kandungan unsur Kalium dalam pupuk organik cair dapat meningkatkan perkembangan dan pertumbuhan akar lateral tanaman, dimana hal ini dapat mempengaruhi tanaman dalam menyerap air. Perbedaan inilah yang menyebabkan setiap 
tanaman menyerap jumlah kadar air yang berbeda-beda. Hal tersebut sejalan dengan pendapat Parman (2007), yang menyatakan bahwa, kandungan unsur Kalium dalam pupuk organik cair dapat meningkatkan perkembangan dan pertumbuhan akar lateral tanaman.

Tinggi Tanaman. Berdasarkan hasil analisis statistik tinggi tanaman rami, terlihat bahwa kombinasi pemberian konsentrasi giberelin dan pupuk organik cair memberikan pengaruh nyata terhadapa tinggi tanaman rami pada umur tanaman 6 MST, 8 MST, 10 MST, dan 12 MST.

Berdasarkan hasil uji lanjut seperti yang tertera pada Tabel 5, pemberian kombinasi konsentrasi giberelin dan pupuk organik cair yang memiliki nilai rata-rata tertinggi adalah perlakuan H (GA $150 \mathrm{ppm}+40 \mathrm{ml} / \mathrm{L}$ POC). Pengaruh perlakuan $\mathrm{H}$ berbeda nyata dengan perlakuan lainnya, kecuali dengan pengaruh perlakuan D.

Tabel 5. Pengaruh Konsentrasi Giberelin dan pupuk Organik Cair Rami terhadap Tinggi Tanaman Rami Klon Ramindo 1 pada 6 MST, 8 MST, 10 MST, dan 12 MST.

\begin{tabular}{ccccc}
\hline \hline \multirow{2}{*}{$\begin{array}{c}\text { Perla- } \\
\text { kuan }\end{array}$} & \multicolumn{4}{c}{ Tinggi Tanaman $(\mathrm{cm})$} \\
\cline { 2 - 5 } & $6 \mathrm{MST}$ & $8 \mathrm{MST}$ & $10 \mathrm{MST}$ & $12 \mathrm{MST}$ \\
\hline $\mathrm{A}$ & $159.4 \mathrm{c}$ & $237,80 \mathrm{~d}$ & $330,25 \mathrm{~d}$ & $412,00 \mathrm{~d}$ \\
$\mathrm{~B}$ & $180.37 \mathrm{bc}$ & $308,85 \mathrm{bc}$ & $433,55 \mathrm{~b}$ & $510.00 \mathrm{bc}$ \\
$\mathrm{C}$ & $190.87 \mathrm{bc}$ & $336,87 \mathrm{ab}$ & $456,42 \mathrm{~b}$ & $540,50 \mathrm{ab}$ \\
$\mathrm{D}$ & $221.67 \mathrm{ab}$ & $345,00 \mathrm{ab}$ & $521,75 \mathrm{a}$ & $560,00 \mathrm{ab}$ \\
$\mathrm{E}$ & $173.22 \mathrm{bc}$ & $274,65 \mathrm{~cd}$ & $370,02 \mathrm{~cd}$ & $458,50 \mathrm{~cd}$ \\
F & $187.22 \mathrm{bc}$ & $314,70 \mathrm{abc}$ & $422,12 \mathrm{bc}$ & $513,25 \mathrm{bc}$ \\
$\mathrm{G}$ & $206.90 \mathrm{abc}$ & $341,42 \mathrm{ab}$ & $436,57 \mathrm{~b}$ & $547,00 \mathrm{ab}$ \\
$\mathrm{H}$ & $254.4 \mathrm{a}$ & $376,50 \mathrm{a}$ & $539,12 \mathrm{a}$ & $603,25 \mathrm{a}$ \\
\hline \hline
\end{tabular}

Keterangan : Nilai rata-rata perlakuan yang ditandai dengan huruf yang sama pada kolom yang sama, menunjukkan tidak berbeda nyata menurut uji jarak berganda Duncan pada taraf $5 \%$.

Pemberian kombinasi larutan GA dan POC pada tanaman rami dapat mempengaruhi salah satu faktor pertumbuhan tanaman rami, yaitu tinggi tanaman. Hal ini disebabkan karena giberelin berperan dalam memacu pertumbuhan dan perkembangan tanaman. Apabila giberelin diaplikasikan pada tanaman, maka dalam tanaman akan terjadi pembelahan dan pertumbuhan sel, kearah pemanjangan batang dan perkembangan daun, dimana perkem-bangan daun berkaitan dengan meningkatnya laju fotosintesis, sehingga akan terjadi pening-katan pertumbuhan pada seluruh organ tanaman (Sitanggang dkk., 2015).

Menurut Gardner dkk. (1991), untuk pertumbuhan dan perkembangan, tanaman membutuhkan unsur $\mathrm{N}$ karena terkait dengan proses pembelahan sel. Pembelahan sel yang terjadi akan meningkatkan jumlah sel dalam tanaman, sehingga tanaman akan semakin panjang atau tinggi. $\mathrm{N}$ juga diperlukan dalam pertumbuhan organ-organ vegetatif tanaman, dimana salah satunya adalah tinggi tanaman.

Diameter Batang Tanaman. Hasil analisis statistik menunjukkan bahwa, kombinasi konsentrasi giberelin dan pupuk organik cair asal rami menghasilkan pengaruh yang berbeda nyata terhadap diameter batang tanaman pada umur 6, 8, 10 dan 12 MST (Tabel 6).

Tabel 6. Pengaruh Konsentrasi Giberelin dan pupuk Organik Cair Rami terhadap Diameter Batang Tanaman (mm) Rami Klon Ramindo 1 pada 6 MST, 8 MST, 10 MST, dan 12 MST.

\begin{tabular}{ccccc}
\hline \hline Perla- & \multicolumn{4}{c}{ Diameter Batang $(\mathrm{mm})$} \\
\cline { 2 - 5 } kuan & $6 \mathrm{MST}$ & $8 \mathrm{MST}$ & $10 \mathrm{MST}$ & $12 \mathrm{MST}$ \\
\hline $\mathrm{A}$ & $24,87 \mathrm{a}$ & $26,47 \mathrm{c}$ & $31,60 \mathrm{~d}$ & $34,47 \mathrm{~d}$ \\
B & $24,50 \mathrm{a}$ & $29,52 \mathrm{bc}$ & $35,50 \mathrm{~cd}$ & $39,30 \mathrm{bcd}$ \\
$\mathrm{C}$ & $26,12 \mathrm{a}$ & $28,95 \mathrm{bc}$ & $37,27 \mathrm{bc}$ & $39,67 \mathrm{bcd}$ \\
$\mathrm{D}$ & $24,52 \mathrm{a}$ & $33,42 \mathrm{ab}$ & $40,90 \mathrm{ab}$ & $44,85 \mathrm{~b}$ \\
E & $24,67 \mathrm{a}$ & $28,65 \mathrm{c}$ & $34,82 \mathrm{~cd}$ & $37,47 \mathrm{~cd}$ \\
F & $24,17 \mathrm{a}$ & $27,60 \mathrm{c}$ & $37,67 \mathrm{bc}$ & $39,95 \mathrm{bcd}$ \\
G & $26,75 \mathrm{a}$ & $30,40 \mathrm{abc}$ & $37,52 \mathrm{bc}$ & $41,95 \mathrm{bc}$ \\
H & $28,2 \mathrm{a}$ & $34,47 \mathrm{a}$ & $45,02 \mathrm{a}$ & $53,15 \mathrm{a}$ \\
\hline \hline
\end{tabular}

Keterangan : Nilai rata-rata perlakuan yang ditandai dengan huruf yang sama pada kolom yang sama, menunjukkan tidak berbeda nyata menurut uji jarak berganda Duncan pada taraf $5 \%$.

Pengaruh kombinasi giberelin dan pupuk organik cair konsentrasi GA 150 ppm $+40 \mathrm{ml} / \mathrm{L}$ POC (perlakuan $\mathrm{H}$ ), menghasilkan tanaman dengan nilai rata-rata diameter batang yang paling besar dibandingkan pengaruh perlakuan lainnya, namun pengaruh perlakuan $\mathrm{H}$ tidak berbeda nyata dengan pengaruh perlakuan $\mathrm{D}$. Pengaruh perlakuan yang memiliki rata-rata diameter batang yang kecil adalah pengaruh perlakuan A (GA 0 ppm + tanpa POC).

Pemberian kombinasi giberelin dan pupuk organik cair pada tanaman rami, dapat meningkatkan diameter batang rami, dimana menurut Fahmi (2013), giberelin dapat memacu pertumbuhan tanaman dengan mempercepat proses pembelahan dan pertumbuhan sel. Aplikasi giberelin pada tanaman dengan konsentrasi yang lebih banyak akan meningkatkan pembentukan floem dibanding xylem. Hal inilah yang menyebabkan pertambahan ukuran pada diameter batang tanaman.

Pupuk organik cair juga dapat mendukung peningkatan diameter batang rami. Keberadaan pupuk $\mathrm{K}$ juga akan menjamin fungsi daun 
dalam hal fotosisntesis, dimana fotosinetsis akan menghasilkan karbohidrat yang nantinya akan menjadi energi yang bermanfaat untuk pembesaran organ tubuh tanaman, salah satunya diameter batang.

Bobot Segar Batang Per Rumpun (g). Bobot segar batang dapat memberikan gam-baran jumlah serat yang dapat dihasilkan oleh tanaman rami tersebut. Bobot segar batang dipengaruhi oleh beberapa faktor, yaitu tinggi tanaman dan diameter batang, dimana semakin tinggi tanaman rami yang dihasilkan dan semakin besar diameter batangnya, maka bobot segar tanaman yang dihasilkan akan semakin besar dan serat yang dihasilkan pun akan semakin banyak, karena serat serat tanaman rami berada pada batang tanaman rami itu sendiri.

Berdasarkan hasil analisis statistik bobot segar tanaman rami, pemberian kombinasi konsentrasi giberelin dan pupuk organik cair asal rami, memberikan pengaruh pada bobot segar batang rami (Tabel 7).

Tabel 7. Pengaruh Konsentrasi Giberelin dan pupuk Organik Cair Rami terhadap Bobot Segar Batang Per Rumpun Tanaman Rami Klon Ramindo 1 pada 12 MST.

\begin{tabular}{cc}
\hline \hline Perlakuan & Bobot Segar Batang $(\mathrm{g})$ \\
\hline A & $260,00 \mathrm{~b}$ \\
B & $288,75 \mathrm{~b}$ \\
C & $301,25 \mathrm{~b}$ \\
D & $375,00 \mathrm{a}$ \\
E & $295,00 \mathrm{~b}$ \\
F & $250,00 \mathrm{~b}$ \\
G & $365,00 \mathrm{a}$ \\
H & $403,75 \mathrm{a}$ \\
\hline \hline
\end{tabular}

Keterangan : Nilai rata-rata perlakuan yang ditandai dengan huruf yang sama pada kolom yang sama, menunjukkan data tidak berbeda nyata menurut uji lanjut Duncan taraf $5 \%$.

Berdasarkan hasil uji lanjut yang dilakukan, perlakuan H (GA $150 \mathrm{ppm}+40 \mathrm{ml} / \mathrm{L}$ POC) menghasilkan bobot segar batang yang lebih besar dan berbeda nyata dengan perlakuan A, B, $C$, E, dan $F$, namun tidak berbeda nyata dengan perlakuan D dan G. Hal sejaan dengan pengaruh perlakuan terhadap faktor tinggi tanaman (Tabel 5) dan diameter tanaman (Tabel 6), pada pengamatan tinggi dan diameter tanaman, perlakuan $\mathrm{H}$ memiliki nilai yang lebih besar dibanding perlakuan lainnya.

Pemberian kombinasi giberelin dan POC pada tanaman rami, dapat mempengaruhi hasil bibit segar batang rami per rumpun. Hal ini disebabkan karena giberelin sebagai zat penga- tur tumbuh yang berperan dalam pembelahan sel dan pertumbuhan sel, mampu mempengaruhi tanaman rami dalam pembentukan tinggi tanaman dan diameter batang (Mudyantini, 2008).

\section{Kesimpulan}

1. Pemberian kombinasi giberelin (GA) dan pupuk organik cair (POC) asal tanaman rami memberikan pengaruh pada pertumbuhan dan hasil serat tanaman rami klon Ramindo 1.

2. Pemberian kombinasi konsentrasi larutan giberelin (GA) $150 \mathrm{ppm}+40 \mathrm{ml} / \mathrm{L}$ pupuk organik cair (POC) asal rami dapat memberikan pengaruh palig baik terhadap pertumbuhan dan hasil tanaman rami klon Ramindo 1.

Saran Sebaiknya dilakukan percobaan lebih lanjut pada konsentrasi giberelin dan pupuk organik cair asal rami pada panen tanaman rami ke 2, 3, dan selanjutnya untuk mengetahui sampai sejauh mana kombinasi konsentrasi giberelin dan pupuk organik cair dapat mempengaruhi pertumbuhan dan hasil serat tanaman rami klon Ramindo 1.

\section{Ucapan Terima Kasih}

Percobaan ini dibiayai oleh Penelitian Unggulan Strategis Nasional (PUSNAS), Oleh sebab itu penulis mengucapkan terima kasih pada DRPM UNPAD dan semua pihak yang terlibat dalam percobaan ini.

\section{Daftar Pustaka}

Juhana A, Musa H, Pandjaitan N H. 2011. Prospek Ekonomi dan Strategi Pengembangan Kapas Rami sebagai Bahan Baku Alternatif Industri Tekstil Skala Usaha Kecil (Kasus Koppontren Darussalam, Garut-Jawa Barat). Available at :http://repository. ipb.ac.id/handle/123456789/52878. 20 Maret 2016.

Musaddad, M. A. 2007. Agribisnis Tanaman Rami. Hal 28-30. Penebar Swadaya.Depok.

Purwati, R.D .2010.Strategi Pengembangan Rami (Boehmeria nivea Gaud.). Available at : http:// perkebunan.litbang.pertanian.go.id /. Diakses pada tanggal 21 Juni 2015.

Tim Puslitbang. 2012. Pemanfaatan Serat Rami untuk Pembuatan Selulosa. Available at : 
http://buletinlitbang.dephan.go.id/. Diakses 22 Juni 2015. 19.57.

Sujdatmiko. 2013. Budidaya Tanaman Rami. Hal.62. Pustaka Baru Press. Yogyakarta.

Syafi'i ,M. 2005. Pengaruh Konsentrasi dan Waktu Pemberian Giberelin (GA) Terhadap Pertumbuhan dan Hasil Tanaman Melon (Cucumis melo I.) dengan Sistem Tanam Hidroponik Irigasi Tetes. Available at :http://core.ac.uk/. Diakses 09 Sept 2015.

Mudyantini, W. 2008. Pertumbuhan, Kandungan Selulosa, dan Lignin pada Rami (Boehmeria nivea L. Gaudich) dengan Pemberian Asam Giberelat (GA) .Available at :

http://biodiversitas.mipa.uns.ac.id/.

Diakses 10 September 2015. Pukul 09.45.

Marupaey, A. 2013. Efek Berbagai Konsentrasi Zat Pengatur Tumbuh $\mathrm{GA}_{3}$ Terhadap Dinamika Pertumbuhan Setek Tebu. Available at : http://www. jurnal.lipi.go.id/ data/1330473786/data/1377780020.doc.

Diakses 20 Maret 2016.

Leovini, H. 2012. Pemanfaatan Pupuk Organik Cair pada Budidaya Tanaman Tomat
(Solanum lycopersicum L.). Available at : https://Felisa.ugm.ac.id. Diakses 21 September 2015. 21.33.

Fahmi, Z. I .2013. Pengaruh Pemberian Hormon Giberelin terhadap Perkecambahan Benih Tanaman. Available at : http:// ditjenbun. pertanian.go.id/bbpptpsurabaya/. Diakses 9 September 2015. Pukul 22.37.

Gardner, F. P, R. B. Pearce dan R. L. Mithchell. 1991. Fisiologi Tanaman Budidaya. Terj. H. Susilo dan Subiyanto. UI Press. Jakarta.

Munawar, A. 2011. Kesuburan Tanah dan Nutrisi Tanaman. IPB Press. Bogor.

Parman, S. 2007. Pengaruh Pemberian Pupuk Organik Cair terhadap Pertumbuhan dan Produksi Kentang (Solanum tuberosum L.). Available at :core.ac.uk/. Diakses 21 April 2016. Pukul 11.39.

Sitanggang, A., Islan, S., I. Saputra. 2015. Pengaruh Pemberian Pupuk Kandang Ayam dan Zat Pengatur Tumbuh GIberelin terhadap Pertumbuhan Bibit Kopi Arabika (Coffea Arabica L.). Available at : jom.unri. ac.id. Diakses 21 April 2016. Pukul 12.13. 